\title{
PELATIHAN PENELITIAN TINDAKAN SEKOLAH MELALUI IMPLEMENTASI REFLECTIVE MODEL PADA PENGAWAS DAN KEPALA SEKOLAH SD DI KECAMATAN BULELENG
}

\author{
oleh, \\ Putu Kerti Nitiasih \\ Fakultas Bahasa dan Seni \\ Universitas Pendidikan Ganesha
}

\begin{abstract}
ABSTRAK
Pengabdian Kepada Masyarakat ini bertujuan untuk memberikan pelatihan kepada Pengawas dan Kepala Sekolah di kecamatan Buleleng tentang Penelitian Tindakan Kelas dengan menggunakan model pelatihan Reflektif. Hasil pelatihan ini dapat meningkatkan kemampuan Pengawas dan Kepala Sekolah dalam : (1) menentukan permasalahan- permasalahan sekolah, (2) menemukan cara memperbaiki (treatment) terhadap masalah-masalah yang dihadapi sekolah, (3) menyusun usulan Penelitian Tindakan Sekolah dan melaksanakannya sebagai kegiatan pengembangan profesinya sebagai pengawas dan kepala sekolah. Hasil pengabdian ini dapat Meningkatkan kemampuan Pengawas dan Kepala Sekolah dalam memberikan informasi yang benar dan memotivasi guru untuk mampu melaksanakan Penelitian Tindakan Kelas sebagai kegiatan pengembangan profesi guru
\end{abstract}

Kata-kata kunci: PTK, reflective model, pengabdian masyarakat

\begin{abstract}
This community Services aimed at giving training to school principals and supervisor of elementary school in Singaraja about Action Research by implementing reflective model. The result of the training could improve the ability of supervisors and school principles in: (1) determining the school problem under their supervision, (2) determining the treatment for the identified problems,(3) designing an action research proposal and implementing the proposal as a part of their proffesionalism as school principals and school supervisors. The result of this cummunity services could also increase the ability of school principals and school supervisors to give appropriate information about action research that finally could motivate them to do a classroom action research for their teaching as a part of their teaching proffesionalism.
\end{abstract}

Key words : action research, reflective model, community services 


\section{Pendahuluan}

Salah satu peran dari seorang pengawas dan kepala sekolah adalah sebagai agent of change bagi kemajuan sekolah. Untuk melaksanakan peran tersebut seorang pengawas harus memiliki kemampuan metodologi untuk melakukan penelitian, sekaligus mengupayakan tindakan untuk memperbaiki keadaan. Disamping sebagai agent of change, tuntutan sertifikasi menuntut kepala sekolah melakukan Penelitian Tindakan Sekolah. Hasil wawancara dengan peserta pelatihan Kepala Sekolah Madrasah menyatakan bahwa hampir 95 \% Kepala Sekolah tidak bisa membuat Penelitian yang cocok untuk seorang Kepala Sekolah serta menulis karya ilmiah. Hasil wawancara ini juga diperkuat oleh hasil penelitian yang dilakukan oleh Nitiasih (2009) bahwa 85\% guru dan 90\% kepala sekolah tidak mampu menemukan masalah yang dapat dijadikan penelitian tindakan kelas untuk guru-guru dan penelitian tindakan sekolah untuk Kepala Sekolah dan Pengawas.

Kenyataan tersebut disupport oleh hasil dari FGD (Focused group discussion) yang dilakukan oleh Rinjin dkk (2008) dengan para guru, yang mana diperoleh informasi bahwa Guru sesungguhnya sering dikirim oleh pihak sekolah untuk mengikuti pelatihan-pelatihan atau seminar tentang PTK atau topik-topik yang lain demikian juga dengan kepala sekolah sering mengikuti pelatihan PTK, tetapi para guru mengakui bahwa model pelatihan lebih banyak memfokuskan pada kajian teoritis dan kurang penyajian contoh-contoh kongkret sehingga ketika selesai mengikuti pelatihan mereka tidak memahami dengan baik konsep yang telah diajarkan dan ketika kembali ke sekolah mereka kembali tidak mampu melakukan penelitian. Sejalan dengan hal tersebut, hasil dari tracer study (Padmadewi, Artini dan Heri Santosa, 2010) juga menyebutkan bahwa para guru memerlukan pelatihan-pelatihan yang menyangkut halhal yang lebih inovatif yang bisa dipakai guru di kelas. Dalam diskusi dengan responden saat itu, juga didapat informasi bahwa model pelatihan yang sering diberikan kepada mereka lebih banyak teoretis dan kurang penyajian contoh kongkret yang aplikatif.

Berdasarkan hasil penelitain di atas, kepala sekolah dan pengawas sebagai orang yang HARUS tahu penelitian terutama PTK dan PTS perlu diberikan pelatihan tentang PTS dengan cara yang lebih praktis sehingga mereka mampu menganalisis dan menemukan masalah-masalah yang cocok dipergunakan sebagai masalah penelitian di 
Sekolah. Tujuan utama Penelitian Tindakan Sekolah adalah untuk memecahkan permasalahan nyata yang terjadi di dalam sekolah-sekolah yang berada dalam binaan pengawas sekolah. Kegiatan penelitian ini tidak saja bertujuan untuk memecahkan masalah, tetapi sekaligus mencari jawaban ilmiah mengapa hal tersebut dapat dipecahkan dengan tindakan yang dilakukan.

Secara lebih rinci, tujuan Penelitian Tindakan Sekolah antara lain : (1) meningkatkan mutu isi, masukan, proses, dan hasil pendidikan, manajemen dan pembelajaran, termasuk mutu guru, kepala sekolah, khususnya yang berkaitan dengan tugas profesional kepengawasan, di sekolah-sekolah yang menjadi binaannya; (2) meningkatkan kemampuan dan sikap profesional sebagai pengawas sekolah; (3) menumbuhkembangkan budaya akademik di lingkungan sekolah sehingga tercipta sikap proaktif di dalam melakukan perbaikan mutu pendidikan.

Ciri khusus dari Penelitian Tindakan Sekolah adalah adanya tindakan (action) yang nyata. Tindakan itu dilakukan pada situasi alami (pada keadaan yang sebenarnya) dan ditujukan untuk memecahkan permasalahan-permasalahan praktis dalam peningkatan mutu proses dan hasil kepengawasan.

Dengan melihat hasil penelitian Nitiasih (2010) bahwa model pelatihan 'Reflective' mampu meningkatkan kemampuan peserta pelatihan dalam membuat proposal PTK maka merupakan suatu keharusan bila para pengawas dan kepala sekolah SD di kecamatan Banjar diberikan pelatihan Penelitian Tindakan Sekolah dengan cara yang lebih kongkrit yaitu dengan 'reflective model' sehingga profesionalisme pengawas dan kepala sekolah tidak TETAP rendah.

Reflective model adalah model pelatihan Penelitian Tindakan kelas yang merupakan hasil penelitian Strategis Nasional (Nitiasih, 2009). Dari hasil penelitian menunjukkan bahwa model ini sangat membantu Guru-Guru dalam menganalisis permasalahan permasalahan pembelajaran yang dapat diangkat sebagai masalah dalam PTK serta meningkatkan kemampuan Guru-Guru dalam membuat proposal penelitian dan melaksanakan PTK dalam pembelajaran. Mengingat permasalahan utama dari Pengawas dan Kepala Sekolah adalah rendahnya kemampuan mereka dalam menemukan masalah yang dapat dipergunakan sebagai topik penelitian terutama Penelitian Tindakan Sekolah, perlu dilakukan Pelatihan Penelitian Tindakan Sekolah 
yang mengimplementasikan 'Model Reflective' yang sudah terbukti mampu meningkatkan kemampuan Guru dalam PTK.

Dari beberapa model pelatihan yang ada, Model Pelatihan Penelitian Tindakan Kelas Reflectif ini adalah model yang paling lengkap, karena dalam model pelatihan ini ada proses pemberian received knowledge sehingga guru memiliki pengetahuan yang lengkap tentang Penelitian Tindakan Kelas.Di samping proses tersebut ada juga proses pemberian previous experiential knowledge dimana guru secara langsung diberi kesempatan untuk merefleksi kualitas proses belajar mengajar yang dilakukan seharihari. Dengan menggabungkan kedua pengetahuan tersebut guru mampu mendeteksi masalah pembelajarannya, mendeteksi factor-faktor yang menjadi penyebab masalah tersebut dan selanjutnya guru mampu memilih metode yang tepat untuk menanggulangi permasalahan pembelajaran yang ditemukan Pada akhirnya setelah mengikuti pelatihan dengan model ini, guru mampu membuat proposal Penelitian Tindakan Kelas sendiri tanpa mencontoh yang sudah ada.

Dengan kata lain, dengan menggunakan model ini peserta akan mampu mengembangkan dua pengetahuan sekaligus yaitu yang diterima oleh peserta dari instruktur dan pengetahuan praktis yang sudah dimiliki oleh peserta yang berhubungan dengan pekerjaan mereka sendiri. Berdasarkan kedua pengetahuan tersebut, peserta dapat melakukan refleksi dengan baik tentang permasalahan-permasalahan yang dihadapi pada pembelajarannya, mencari faktor-faktor yang menjadi penyebab masalah tersebut melalui refleksi tentang dan mencari solusi dari permasalahan. Model pelatihan ini dapat digambarkan sebagai berikut :

Berdasarkan hasil observasi yang dilakukan di Dinas Pendidikan dan Kebudayaan (Kamis 23 Agustus) ditemukan bahwa dari 84 Kepala Sekolah dan 23 Pengawas SD hanya $12 \%$ yang melakukan PTK dengan benar. Sebanyak $52 \%$ membuat PTS sebagai persyaratan kenaikan pangkat dari menyuruhkan dan $36 \%$ menyatakan tidak pernah mengerti apa itu PTS. Berdasarka kenyataan tersebut maslah-masalah yang dihadapi pengawas dan kepala sekolah dapat diidentifikasi sbg berikut : (1) Rendahnya kemampuan Pengawas dan Kepala Sekolah dalam menemukan dan menentukan permasalahan- permasalahn sekolah yang dapat dipergunakan sebagai masalah PTS, (2) Rendahnya kemampuan Pengawas dan Kepala Sekolah dalam menemukan cara 
memperbaiki (treatment) terhadap masalah-masalah yang dihadapi sekolah, (3) Rendahnya kemampuan Pengawas dan Kepala Sekolah dalam menyusun usulan Penelitian Tindakan Sekolah dan melaksanakannya sebagai kegiatan pengembangan profesinya sebagai pengawas dan kepala sekolah. Berdasarkan permasalahan diatas Rumusan Masalah Pengabdian Masyarakat ini adalah : Apakah Kemampuan Pengawas dan Kepala Sekolah dalam menyusun usulan Penelitian Tindakan Sekolah dapat ditingkatkan melalui Pelatihan PTS dengan 'Reflective Model'?

Berdasarkan permasalahan yang dihadadapi oleh Pengawas dan Kepala Sekolah seperti yang disampaikan di atas, maka tujuan kegiatan ini adalah Memberikan Pelatihan Penelitian Tindakan Sekolah yang dapat : (1) Meningkatkan kemampuan Pengawas dan Kepala Sekolah dalam menemukan dan menentukan permasalahanpermasalahan sekolah yang dapat dipergunakan sebagai masalah PTS, (2) Meningkatkan kemampuan Pengawas dan Kepala Sekolah dalam menemukan cara memperbaiki (treatment) terhadap masalah-masalah yang dihadapi sekolah, (3) Meningkatkan kemampuan Pengawas dan Kepala Sekolah dalam menyusun usulan Penelitian Tindakan Sekolah dan melaksanakannya sebagai kegiatan pengembangan profesinya sebagai pengawas dan kepala sekolah, (4) Meningkatkan kemampuan Pengawas dan Kepala Sekolah dalam melaksanakan dan melaporkan hasil penelitiannya, dan (5) Meningkatkan kemampuan Pengawas dan Kepala Sekolah dalam memberikan informasi yang benar dan memotivasi guru untuk mampu melaksanakan Penelitian Tindakan Kelas sebagai kegiatan pengembangan profesi guru.

Hasil Kegiatan pengabdian pada masyarakat ini akan memberikan kontribusi positif dalam meningkatkan profesionalisme Pengawas dan Kepala sekolah di kecamatan Banjar. Secara lebih eksplisit manfaat kegiatan ini adalah sebagai berikut: (a) Pengawas dan Kepala Sekolah yang terlibat dalam kegiatan pelatihan ini memperoleh wawasan tentang : (1) bagaimana menemukan dan menentukan masalah-masalah sekolah yang dapat dipergunakan sebagai masalah PTS; (2) bagaimana menemukan cara memperbaiki (treatment) terhadap masalah-masalah yang dihadapi sekolah; (3) bagaimana menyusun usulan Penelitian Tindakan Sekolah dan melaksanakannya sebagai kegiatan pengembangan profesinya sebagai pengawas dan kepala sekolah, 
(c) Dinas Pendidikan dan Kebudayaan memperoleh peluang untuk memiliki SDM (pengawas dan Kepala sekolah) yang berkualitas dan profesional, dan (d) Staf Dosen Universitas Pendidikan Ganesha dapat mengimplementasikan hasil penelitian yang dilakukan. Secara umum Staf Dosen Universitas Pendidikan Ganesha dapat melaksanakan salah satu darma dari tri dharma Perguruan Tinggi yaitu Pengabdian Pada Masyarakat.

Secara umum, tujuan pengabdian pada masyarakat (P2M) ini adalah untuk meningkatkan profesionalisme Pengawas dan Kepala Sekolah dalam merancang dan melaksanakan Penelitian Tindakan Sekolah. Sehubungan dengan hal tersebut, khalayak sasaran strategis dan tepat dilibatkan adalah seluruh pengawas SD dan kepala Sekolah SD di Kecamatan Buleleng yang berjumlah 40 orang. Pemilihan kecamatan Banjar sebagai sasaran mengingat kecamatan Buleleng dipergunakan sebagai model bagi kecamatan-kecamatan lainnya.

\section{Metode Pelaksanaan Pengabdian}

Bentuk aktivitas menggunakan strategi pelatihan (training). Tahapan-tahapan aktivitas secara umum yaitu: penyemaian informasi (encoding), pengintegrasian informasi menjadi suatu pemahaman (decoding), perekaman informasi (storing), dan pembelajaran informasi (learning). Seluruh aktivitas tersebut dirancang bersama-sama dan dilakukan dalam situasi informal dengan melakukan pelatihan dan pendampingan terhadap pengawas dan kepala sekolah SD di kecamatan Banjar. Secara lebih spesifik sintaks pelatihan dengan model reflektif ini dapat dilihat dalam bagain berikut:

\begin{tabular}{|c|c|c|}
\hline \multirow[t]{2}{*}{ Fase } & \multicolumn{2}{|c|}{ Aktivitas } \\
\hline & Trainer & Trainee \\
\hline $\begin{array}{l}\text { 1. Receive knowledge } \\
\text { (pemberian informasi) }\end{array}$ & \begin{tabular}{|l} 
1. \\
Menyampaikan materi dengan \\
gaw \\
2. Ada beberapa materi yang diberikan \\
dengan jig-saw yang mengharuskan \\
pembentukan kelompok \\
3. Pemberian model PTS
\end{tabular} & $\begin{array}{ll}\text { 1. } & \text { Mendengarkan dan } \\
& \text { memperhatikan materi yang } \\
& \text { disampaikan } \\
\text { 2. } & \text { Membentuk kelompok dan } \\
& \text { mengerjakan pelatihan sesuai } \\
& \text { dengan instruksi untuk } \\
& \text { pelaksanaan jig-saw }\end{array}$ \\
\hline $\begin{array}{l}\text { 2. Previous } \\
\text { experiencial knowledge } \\
\text { (refleksi) }\end{array}$ & $\begin{array}{l}\text { 1. Meminta peserta untuk merefleksi } \\
\text { pembelajarannya terutama pada } \\
\text { aspek-aspek : permasalahan, sumber }\end{array}$ & $\begin{array}{ll}\text { 1. } & \text { Melakukan refleksi terhadap } \\
\text { masalah pembelajaran yang } \\
\text { dihadapi di kelasnya, penyebab }\end{array}$ \\
\hline
\end{tabular}




\begin{tabular}{|c|c|c|}
\hline & $\begin{array}{l}\text { masalah dan cara pemecahan masalah } \\
\text { 2. Meminta peserta pelatihan } \\
\text { menuliskannya dalam pendahuluan }\end{array}$ & $\begin{array}{l}\text { masalah tersebut dan cara } \\
\text { pemecahan masalahnya } \\
\text { 2. } \begin{array}{l}\text { Menuliskan dalam pendahuluan } \\
\text { dari proposal masing-masing }\end{array}\end{array}$ \\
\hline $\begin{array}{l}\text { 3. Practice } \\
\text { a. Praktik penyusunan } \\
\text { proposal } \\
\text { b.Presentasi } \\
\text { proposal } \\
\text { c. Presentasi cara } \\
\text { pemecahan masalah }\end{array}$ & $\begin{array}{l}\text { 1. Melatih menyusun bagian perbagian } \\
\text { dari sebuah proposal } \\
\text { 2. Meminta peserta untuk } \\
\text { mempresentasikan hanya bagian } \\
\text { penting dari proposal: masalah, latar } \\
\text { belakang masalah dan cara } \\
\text { pemecahan masalah. } \\
\text { 3. Meminta peserta untuk melakukan } \\
\text { simulasi tentang metode, strategi } \\
\text { pembelajaran atau cara evaluasi yang } \\
\text { dipergunakan sebagai cara } \\
\text { pemecahan masalah }\end{array}$ & 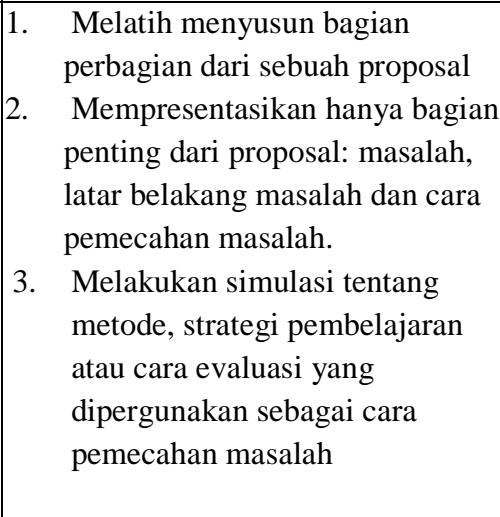 \\
\hline 4. Reflect (refleksi) & $\begin{array}{l}\text { 1. Meminta peserta melakukan refleksi } \\
\text { terhadap proposal yang sudah dibuat } \\
\text { 2. Meminta peserta melakukan refleksi } \\
\text { terhadap kemungkinan dampak dari } \\
\text { cara pemecahan masalah yang } \\
\text { disimulasikan }\end{array}$ & $\begin{array}{l}\text { 1. Melakukan refleksi terhadap } \\
\text { proposal yang sudah dibuat } \\
\text { 2. Melakukan refleksi terhadap } \\
\text { kemungkinan dampak dari cara } \\
\text { pemecahan masalah yang } \\
\text { disimulasikan }\end{array}$ \\
\hline $\begin{array}{l}\text { 5. Proffesional } \\
\text { Competence } \\
\text { Perbaikan proposal yg } \\
\text { menunjukkan } \\
\text { kompetensi } \\
\text { profesional guru }\end{array}$ & $\begin{array}{l}\text { Menilai proposal yang sudah dihasilkan } \\
\text { oleh guru }\end{array}$ & $\begin{array}{l}\text { Mencermati hasil penilaian, } \\
\text { merefleksi dan melakukan perbaikan }\end{array}$ \\
\hline
\end{tabular}

Gambar 3. Sintaks pelaksanaan pelatihan dengan model 'Reflective'

\section{Hasil dan Pembahasan}

Hasil evaluasi yang dilakukan oleh Direktorat Pendidikan Dasar dan Menengah menunjukkan bahwa sosialisasi dan pelatihan yang selama ini biasa dilaksanakan belum mampu meningkatkan kemampuan para pengawas dan kepala sekolah dalam penelitian dan pengembangan. Hal tersebut ternyata benar karena dari hasil pre test yang dilaksanakan pada kegiatan P2M ini menunjukkan $55 \%$ peserta mengatakan pernah melakukan penelitian namun 97 dari 55\% tersebut mengatakan tidak tau jenis penelitian apa yang dilakukan, dan $100 \%$ peserta yang pernah melakukan penelitian menyatakan penelitian yang dilakukan hanya untuk persyaratan kenaikan pangkat, $20 \%$ peserta mengatakan pernah mendengar tentang penelitian tindakan sekolah dan $80 \%$ 
mengatakan tidak pernah mendengar ttg PTS, 100\% mengatakan belum pernah melakukan PTS.

Dari permasalahan tersebut selanjutnya dilaksanakan Pelatihan Penelitian Tindakan Sekolah dengan menggunakan model Reflective. Dalam pelaksanaan pelatihan dilaksanakan observasi yang menunjukkan bahwa ketekunan mendengarkan ceramah dari peserta atas materi yang disampaikan ada pada kategori 5 (sangat serius), Dalam melaksanakan kegiatan dilakukan pula beberapa teknik pelatihan yaitu jig saw. Keseriusan dalam melakukan jig saw yang diminta dilakukan oleh peserta juga menunjukkan angka 5 yaitu sangat serius. Keseriusan dalam melakukan refleksi terhadap permasalahan yang dialami di sekolah menunjukkan angka 4 (serius). Hal ini ditunjukkan dgn banyaknya jumlah permasalahan yang dapat diidentifikasi dalam diskusi yang dilakukan. Selanjutnya kejujuran dalam mengemukakan permasalahan yang dialami di sekolah masing-masing ada dalam kategori 3 yaitu cukup serius. Hal ini ditunjukkan berdasarkan permasalahan yang dibuat yang lebih banyak menunjukan permasalahan yang disebabkan oleh guru dan bukan permasalahan peserta sebagai pengawas dan kepala sekolah. Kegiatan memilih masalah yang urgen untuk dilaksanakan menunjukkan angka 4 yaitu ada pada kategori serius. Dalam hal ini peserta sudah mampu mengidentifikasi mana masalah yang urgen dan bisa dipergunakan sebagai penelitian tindakan sekolah dan mana yang tidak bisa dipergunakan untuk PTS. Tanggung jawab dalam melakukan diskusi untuk memilih metode yang sesuai untuk memecahkan masalah yang dialami oleh kepala sekolah dan pengawas menunjukan angka 5 yang ada pada kategori sangat serius. Hasil observasi dalam tahapan ini dilihat dari keseriusan peserta dalam mencari cara pemecahan masalah terhadap masalah yang diidentifikasi. Tanggungjawab untuk menyelesaikan proposal penelitian menunjukan angka 4 (serius) dan keseriusan dalam menulis proposal penelitian ada pada kategori sangat serius. Hasil diatas disebabkan karena para guru merasa sangat perlu dengan pengetahuan tentang PTS. Mereka diberikan pengertian bahwa tujuan utama Penelitian Tindakan Sekolah adalah untuk memecahkan permasalahan nyata yang terjadi di dalam sekolah-sekolah yang berada dalam binaan pengawas sekolah. Kegiatan penelitian ini tidak saja bertujuan untuk 
memecahkan masalah, tetapi sekaligus mencari jawaban ilmiah mengapa hal tersebut dapat dipecahkan dengan tindakan yang dilakukan.

Secara lebih rinci, tujuan Penelitian Tindakan Sekolah antara lain : (1) meningkatkan mutu isi, masukan, proses, dan hasil pendidikan, manajemen dan pembelajaran, termasuk mutu guru, kepala sekolah, khususnya yang berkaitan dengan tugas profesional kepengawasan, di sekolah-sekolah yang menjadi binaannya; (2) meningkatkan kemampuan dan sikap profesional sebagai pengawas sekolah; (3) menumbuhkembangkan budaya akademik di lingkungan sekolah sehingga tercipta sikap proaktif di dalam melakukan perbaikan mutu pendidikan.

Keseriusan tersebut juga disebabkan oleh pengertian yang diperoleh bahwa Penelitian Tindakan Sekolah memerlukan adanya tindakan (action) yang nyata. Tindakan itu dilakukan pada situasi alami (pada keadaan yang sebenarnya) dan ditujukan untuk memecahkan permasalahan-permasalahan praktis dalam peningkatan mutu proses dan hasil kepengawasan.

Hasil dari kesriusan mereka dapat dilihat dari penilaian atas produk pelatihan berupa proposal Penelitian Tindakan Sekolah sebagai berikut : 1) dalam mengidentifikasi kemampuan rata rata peserta adalah 87, 2) dalam menentukan masalah penelitian rerata kemampuan peserta adalah 92. Hal ini merupakan kemajuan luar biasa karena peserta mengetahui mana masalah - masalah yang bisa dipergunakan untuk penelitian. Kemampuan yang lebih baik juga ditunjukkan oleh peserta dalam menentukan sumber masalah yang ada, kebanyakan dari mereka lebih banyak menyalahkan guru dibandingkan menilai diri sendiri. Kemampuan yang paling rendah dari peserta adalah dalam menentukan bukti pendukung untuk masalah penelitian. Penentuan cara pemecahan masalah menunjukkan kemampuan yang baik yaitu 80. Karena kurangnya informasi terhadap teori-teori pembelajaran dan management, kemampuan peserta menulis teori-teori yang relevan juga tidak terlalu baik. Namun pembuatan metode peneltian (termasuk penentuan setting penelitian, subyek penelitian, prosedur penelitian) menunjukkan kemampuan yang sangat baik yaitu 90.Kemampuan dalam metodologi ini jelas sangat mendukung pelaksanaan penelitian nantinya. 


\section{Penutup}

Berdasarkan hasil kegiatan dapat disimpulkan bahwa : (1) Pelatihan Penelitian Tindakan Kelas dengan menggunakan reflective model dapat meningkatkan kemampuan Pengawas dan Kepala Sekolah dalam menemukan dan menentukan permasalahan- permasalahan sekolah yang dapat dipergunakan sebagai masalah PTS, (2) Pelatihan Penelitian Tindakan Sekolah dengan menggunakan 'Reflective Model' dapat meningkatkan kemampuan Pengawas dan Kepala Sekolah dalam menemukan cara memperbaiki (treatment) terhadap masalah-masalah yang dihadapi sekolah, (3) Pelatihan Penelitian Tindakan Sekolah dengan menggunakan 'Reflective Model' dapat meningkatkan kemampuan Pengawas dan Kepala Sekolah dalam menyusun usulan Penelitian Tindakan Sekolah dan melaksanakannya sebagai kegiatan pengembangan profesinya sebagai pengawas dan kepala sekolah, (4) Pelatihan Penelitian Tindakan Sekolah dengan menggunakan 'Reflective Model' dapat meningkatkan kemampuan Pengawas dan Kepala Sekolah dalam melaksanakan dan melaporkan hasil penelitiannya, (5) Pelatihan Penelitian Tindakan Sekolah dengan menggunakan reflective model dapat meningkatkan kemampuan Pengawas dan Kepala Sekolah dalam memberikan informasi yang benar dan memotivasi guru untuk mampu melaksanakan Penelitian Tindakan Kelas sebagai kegiatan pengembangan profesi guru.

\section{DAFTAR PUSTAKA}

Killen, Roy. 1998. Effective Teaching Strategies. Katoomba NSW: Social Science Press

Nitiasih, Putu Kerti, 2010. Model Pelatihan Penelitian Tindakan Kelas Reflektif Berbasis Kompetensi (PTK-RBK) Untuk Meningkatkan Profesionalisme Guru di Provinsi Bali. Hasil Penelitian yang tidak dipublikasikan.

Padmadewi, Ni Nyoman; Artini, Luh Putu; Heri santosa, Made.2008. Studi Penelusuran Alumni tentang Relevansi Kurikulum dengan Kebutuhan Pekerjaan Guru di Sekolah. Hasil penelitian yang tidak dipublikasikan.

Rindjin, Sarna, Padmadewi. 2006. Diagnosis Masalah Pembelajaran (Makalah disampaikan dalam Focused Group Discussion antar Guru-Guru SD, SMP se Kabupaten Banjar tanggal 21 Oktober 2006. 
Rinjin, Nitiasih, Permasalahan-permasalahan dalam pembelajaran (Makalah disampaikan dalam Focused Group Discussion antar Guru-Guru SD, SMP seKabupaten Banjar tahun 2006.

Sugiyono. 2007. Metode Penelitian Pendidikan: Pendekatan Kuantitatif, Kualitatif, dan R\&D. Bandung, Alfabetha Bandung

Tantra, Dewa Komang. 2005. Penelitian Tindakan Kelas (Makalah disampaikan dalam Workshop Menumbuhkan Komitmen Guru dan Pegawai SMA Negeri 4 Denpasar tanggal 3 Januari 2005).

Tantra, D.K. 2005. Peningkatan Profesionalisme Guru dengan Paradigma Baru ( makalah disampaikan dalam workshop menumbuhkan komitmen guru dan pegawai SMA Negeri 3 Denpasar, pada tanggal 3 Januari 2005). 